The Auk 118(2):539-543, 2001

\title{
Latitudinal Variation in Female Local Return Rate in the Philopatric Pied Flycatcher (Ficedula hypoleuca)
}

\author{
JUAN JOSÉ SANZ \\ Departamento de Ecología Evolutiva, Museo Nacional de Ciencias Naturales (CSIC), \\ José Gutiérrez Abascal 2, E-28006 Madrid, Spain
}

\begin{abstract}
Philopatry and dispersal distances of female Pied Flycatcher (Ficedula hypoleuca) are presented for European populations using data from 25 breeding areas from 40 to $70^{\circ} \mathrm{N}$. Female annual survival probabilities according to capture-recapture models were similar in two study areas in central Spain (45 and 52\%). The present study shows that survival is underestimated by using annual local return rate in one of the two breeding populations under study in central Spain. In southern and central Europe, females were found to return equally regularly to their breeding areas, whereas in northern Europe (latitude $>60^{\circ} \mathrm{N}$ ) females returned at lower rates. I did not find that median dispersal distance varied among sites, nor was breeding distance related to locate survival rate. Therefore, the present study suggests that the decline in between-year local return rate of female Pied Flycatchers with increasing latitude over Europe may be more probably caused by differences in mortality than by geographical differences in site fidelity.
\end{abstract}

In many species of birds, adults show high breeding-site fidelity (Greenwood and Harvey 1982). A typical passerine that shows a high level of fidelity to the breeding territory in successive breeding seasons is the Pied Flycatcher (Ficedula hypoleuca) (Lundberg and Alatalo 1992). Because of this, female and male local return rates have repeatedly been used in analyzing annual survival rates (Askenmo 1979, Røskaft et al. 1986, Järvi et al. 1987, Slagsvold and Lifjeld 1988, Alatalo and Lundberg 1989, Potti and Montalvo 1991a, Sanz 1997a, Siikamäki and Hovi 1997, Eeva and Lehikoinen 1998, Hemborg and Lundberg 1998, Hemborg 1999). In those studies, local return rate was often estimated as the proportion of marked individuals realized in one year that were recaptured in the next year. However, local return rate includes both the probability of survival and the probability of recapturing on the next year (Martin et al. 1995), and is affected by dispersal distances. These confounding factors might limit the interpretation of those studies, and it is questionable whether local return rate could be used as a survival estimate (Martin et al. 1995).

In a previous review of female local return rates and breeding dispersal distances from different Eu-

${ }^{1}$ E-mail: sanz@mncn.csic.es ropean populations of Pied Flycatchers (Lundberg and Alatalo 1992), a relatively small number of studies was used ( $n=14$ areas) from a narrow latitudinal range studied ( 50 to $66^{\circ} \mathrm{N}$ ). Because of the large number of studies published on the Pied Flycatcher near the peripheral parts of its range in the Palearctic (Sanz 1997b), it is now possible to analyze geographical variation in those parameters using a relatively large data set ( $n=25$ areas) from a more extensive geographic range $\left(40\right.$ to $\left.70^{\circ} \mathrm{N}\right)$. Most studies of breeding dispersal have concentrated on identifying the factors associated with the movement of birds from previously occupied territory (Pärt and Gustafsson 1989, Potti and Montalvo 1991b). Here, I test (1) whether annual survival rate of female Pied Flycatcher can be estimated from the local return rates on small-scale study plots, and (2) whether female local return rate and breeding dispersal in this species vary with latitude.

Methods.-The Pied Flycatcher is a small, migratory, philopatric, and hole-nesting passerine bird of European woodlands. It leaves Europe for the wintering grounds in west Africa around mid-August (Lundberg and Alatalo 1992), and it returns to the breeding areas during May (Sanz 1997b).

The data presented were collected in two breeding populations in central Spain (Sanz 1995) that were separated by distance of $\sim 20 \mathrm{~km}$ : (a) a montane coniferous forest of Pinus sylvestris (hereafter called Siete Picos) at 1,900-2,000 m a.s.l. near Navacerrada pass, Madrid $\left(40^{\circ} 48^{\prime} \mathrm{N}, 4^{\circ} 01^{\prime} \mathrm{W}\right)$. That study plot is on steep northern slopes close to the tree-limit with a severe climate (Sanz 1995). From 1989 to 1994, 250 nestboxes were checked for occupation by Pied Flycatchers; (b) a deciduous forest of Quercus pyrenaica (hereafter called Valsain) at 1,200 $\mathrm{m}$ a.s.l. near the vicinity of La Granja, Segovia $\left(40^{\circ} 54^{\prime} \mathrm{N}, 4^{\circ} 01^{\prime} \mathrm{W}\right)$. Climate in this area is less harsh (Sanz 1995), and from 1991 to 1999 I checked 150-350 nestboxes for occupation by Pied Flycatchers.

Nestboxes were erected in a grid with $25 \mathrm{~m}$ between adjacent boxes. The nestboxes occupied by Pied Flycatchers were protected to prevent predation and were cleaned every year after the breeding season. Most of the breeding females $(92.4 \%$ in Siete Picos and $91.7 \%$ in Valsain) were caught and identified (or banded if they had not been encountered previously) during incubation or when they were feeding 
TABLE 1. Annual return rate, survival and recapture probabilities (mean $\pm \mathrm{SE}$ ) of the female Pied Flycatchers breeding in Siete Picos and Valsain (central Spain). Data are presented per study year.

\begin{tabular}{|c|c|c|c|c|c|c|}
\hline \multirow[b]{2}{*}{ Year } & \multicolumn{3}{|c|}{ Siete Picos } & \multicolumn{3}{|c|}{ Valsain } \\
\hline & Return rate & Survival & Recapture & Return rate & Survival & Recapture \\
\hline 1989 & 0.2857 & $0.2857 \pm 0.1207$ & $1.00 \pm 0.00$ & & & \\
\hline 1990 & 0.5152 & $1.0000 \pm 0.0000$ & $0.39 \pm 0.08$ & & & \\
\hline 1991 & 0.4242 & $0.4531 \pm 0.1420$ & $0.56 \pm 0.17$ & 0.5000 & $0.5000 \pm 0.0945$ & $1.00 \pm 0.00$ \\
\hline 1992 & 0.2174 & $0.1354 \pm 0.0417$ & $0.86 \pm 0.13$ & 0.3721 & $0.5037 \pm 0.1289$ & $0.47 \pm 0.12$ \\
\hline 1993 & 0.3500 & $0.3889 \pm 0.1905$ & $0.46 \pm 0.16$ & 0.4737 & $0.5316 \pm 0.0970$ & $0.69 \pm 0.09$ \\
\hline 1994 & & & & 0.4667 & $0.4777 \pm 0.0669$ & $0.96 \pm 0.04$ \\
\hline 1995 & & & & 0.4267 & $0.4454 \pm 0.0605$ & $0.86 \pm 0.06$ \\
\hline 1996 & & & & 0.5577 & $0.5894 \pm 0.0766$ & $0.92 \pm 0.06$ \\
\hline 1997 & & & & 0.3474 & $0.3963 \pm 0.0607$ & $0.78 \pm 0.08$ \\
\hline 1998 & & & & 0.3913 & $0.7233 \pm 0.2631$ & $0.54 \pm 0.17$ \\
\hline Mean & 0.3585 & 0.4526 & 0.65 & 0.4420 & 0.5209 & 0.78 \\
\hline
\end{tabular}

the nestlings. The subsequent annual local return rate of females was observed through recapture in the following breeding season. Female annual survival rate was calculated according to the CormackJolly-Seber capture-recapture model (Lebreton et al. 1992) as presented in the program SURGE (Cooch et al. 1997). The capture-recapture model considered was cohort-time dependent for survival and simple time dependent for recaptures (Cooch et al. 1997). The total number of capture histories was $219 \mathrm{fe}-$ males for Siete Picos and 437 females for Valsain. Breeding dispersal of females in Valsain was determined as the distance (to the nearest $5 \mathrm{~m}$ ) between the occupied nestboxes in successive breeding seasons on a detailed map of the study area. To avoid dependence among observations, only the first distance moved by an individual female was used $(n=$ 166).

I used the data from my two study sites and 23 others from across Europe (see Appendix) to exam-

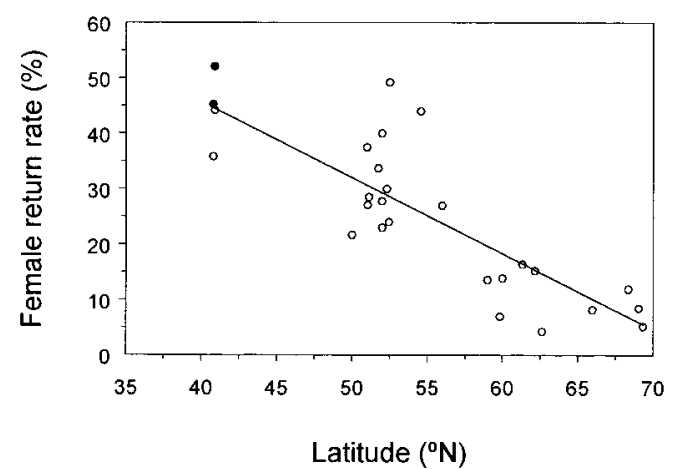

FIG. 1. The relation for the Pied Flycatcher between female annual local return rate and latitude of the study areas $(Y=1.444-0.017 X, r=-0.80, \mathrm{df}=$ $24, P<0.001)$. Black dots represent annual survival rate according to the Cormack-Jolly-Seber capturerecapture model (Lebreton et al. 1992). ine geographic variation in return rate and dispersal distance. The parameters included in the analyses were "annual local return rates" and "breeding dispersal distances" of females. If data for several years were available, the mean values for each study area were used in the analyses. For all areas, the latitude in decimal degrees was determined. I included only latitude in the analyses because the distribution of that species shows a southwest to northeast trend in Europe (Sanz 1997b). Proportions were analyzed after arsine square root transformation. Values are presented as means \pm SD.

Results.-In Siete Picos, the local female return rate $(35.8 \%)$ did not differ significantly (Wilcoxon test, Z $=0.76, \mathrm{df}=5, P=0.46)$ from the calculated female survival rate (45.3\%; Table 1$)$. In Valsain, the local return rate and survival rate of the females in successive breeding seasons were 44.2 and $52.1 \%$, respectively (Table 1). In Valsain, female local return rates in successive breeding seasons was significantly lower than the calculated survival rates (Wilcoxon test, $Z=2.37, \mathrm{df}=8, P=0.018$ ). Mean female annual local return rate of all study sites in western Europe was $23.6 \%$ ( $n=25$ studies). When female local return rates were compared among study sites, there was a significant negative relationship with latitude of the study areas (Fig. 1).

During the study period, female emigration from one population to the other was never observed. Median female breeding dispersal distance in Valsain was $145 \mathrm{~m}$ (range $0-1,215 \mathrm{~m}, n=166$ ). Mean nearest neighbor distance between nestboxes was $25 \mathrm{~m}$. Only $7.2 \%$ of females nested in the same nestbox in consecutive years, and the median number of nestboxes moved between breeding seasons was six. Female breeding dispersal distances did not vary with the latitude for the seven studies that reported dispersal data $(r=0.12, \mathrm{df}=7, P=0.75)$, and no relationship was found between local female return rate and dispersal distance $(r=-0.15, \mathrm{df}=7, P=0.72)$. 
Discussion.- Some investigators working on nestbox studies claim that it is legitimate to ignore capture probability because all nestboxes are checked during the breeding season. If interior zeros in capture histories are noted in such studies (e.g. capture histories such as 1011), then the capture probability parameter may reflect temporary emigration (nonbreeding or nesting in natural cavities). Therefore, capture probability is needed in modeling capture history data regardless of the events it represents (Lebreton et al. 1992). Some unknown number of zeros following final captures reflect birds still alive and in the "superpopulation" of interest (Kendall et al. 1997). If capture probability is not included in the capture probability modeling, annual survival will be underestimated by methods that assume that all birds die in the interval following their final capture.

The present study shows that survival is underestimated by using annual local return rate in one of the two breeding populations under study in central Spain. In central Spain, the annual survival estimates of female Pied Flycatchers were similar in both study areas. Moreover, in southern and central Europe, females were found to return equally regularly to their breeding areas, whereas in northern Europe (latitude $>60^{\circ} \mathrm{N}$ ), females returned at lower rates. The lower return rates in northern Europe might be related to either lower breeding-site fidelity and long distance dispersal, or to higher female mortality. Von Haartman (1960) suggested that the breeding site fidelity of Pied Flycatchers declined towards the north in Europe, but the available evidence (Appendix) does not support that suggestion. I did not find that median dispersal distance varied among sites, nor was breeding distance related to locate survival rate. If the latitudinal trend in return rate was solely a product of differences in philopatry, then dispersal rate would have had to have been $400 \%$ higher in the north, and the data suggest no such difference.

Survival plays a strong role in the evolution of lifehistory tactics through its relationship with fecundity (Roff 1992, Stearns 1992). At an interspecific level, annual survival and clutch size are inversely related (Sæther 1988, Martin 1995). Northern populations of Pied Flycatchers tend to produce larger clutches and raise larger broods (Sanz 1997b), and females may therefore experience higher mortality. The generalization that adult survival and clutch size are inversely related within species is widely accepted (Högstedt 1981, Sæther 1988, Karr et al. 1990, Martin 1995), and intraspecific costs of reproduction might account for the inverse relationship between latitude and return rate in Pied Flycatchers. However, other components of fecundity such as nest success and juvenile survival are also important and must be examined in greater detail to fully evaluate this hypothesis (Bennett and Harvey 1988). Clearly, the latitudinal gradient in return rate that exists in female Pied Flycatchers can only be explained after experimental studies of the cost of reproduction have been conducted at different latitudes. Given my results, survivorship should be measured with markand-recapture statistics that account for dispersal and attempt to separate it from mortality (e.g. Lebreton et al. 1992).

The general idea from previous studies (Lundberg and Alatalo 1992) is that if a Pied Flycatcher has started to breed at a certain site she, if having survived, is very likely to return to the same area in the next breeding season. In Valsain, the present study shows that a few females $(7.2 \%)$ reoccupied their previous nestbox, whereas most of them occupied nestboxes in $<100 \mathrm{~m}$ ( $44 \%$ of females). This low degree of nestbox fidelity has been suggested to be a result of a high frequency of forced movements due to breeding tits (Parus spp.) or to earlier arrived conspecifics (Harvey et al. 1984). Another factor causing a low degree of nestbox fidelity may be the high density of nestboxes (Pärt and Gustafsson 1989). Female Pied Flycatchers are more selective at high than at low nestbox density (Alatalo et al. 1988).

The present study shows a decline in between-year local return rate of female Pied Flycatchers with increasing latitude over Europe. This may be more probably caused by differences in mortality than by geographical differences in site fidelity. Hopefully this study will stimulate more research to solve the problem of latitudinal variation in survival.

Acknowledgments. - I am grateful to J. Moreno, J. A. Fargallo, R. Johnston, S. Merino, E. Arriero, and E. Sotolargo for invaluable help in Valsain. I thank J. D. Nichols, D. G. Krementz, M. T. Murphy, and more anonymous reviewers for helpful comments on the manuscript. This is a contribution from the field station "El Ventorrillo," MNCN-CSIC. I was supported by a contract from the project PB97-1233-C02-01 of the Spanish DGESIC. The Dirección General para la Conservación de la Naturaleza donated the nestboxes, whereas Javier Donés (Montes de Valsain) gave permission to work in the forests. The Dirección General del Medio Natural of the Junta de Castilla y León gave licences for capturing and banding birds.

\section{Literature Cited}

Alatalo, R. V., A. Lundberg, and A. Carlson. 1988. The search cost in mate choice of the Pied Flycatcher. Animal Behaviour 36:289-291.

Alatalo, R. V., And A. Lundberg. 1989. Clutch size of the Pied Flycatcher Ficedula hypoleuca-An experiment. Ornis Fennica 66:15-23.

AsKenMo, C. 1979. Reproductive effort and return rate of male Pied Flycatchers. American Naturalist 114:748-753.

Bennett, P. M., And P. H. Harvey. 1988. How fecundity balances mortality in birds. Nature 333: 216. 
Berndt, R., AND H. Sternberg. 1969. Alter- und Geschelchtsunterschiede in der Dispersion des Trauerschnäppers (Ficedula hypoleuca). Journal für Ornithologie 110:22-26.

Campbell, B. 1959. Attachment of Pied Flycatcher Muscicapa hypoleuca to nest-sites. Ibis 101:445448.

COOCH, E. G., R. Pradel, AND N. Nur. 1997. A practical guide to mark-recapture analysis using SURGE, 2nd ed. Centre d'Ecologie Fonctionelle et Evolutive-CNRS, Montpellier, France.

CReutZ, G. 1955. Der Trauerschnäppers (Muscicapa hypoleuca) (Pallas). Eine populations-studie. Journal für Ornithologie 96:241-326.

CurIo, E. 1959. Beiträge zur Populationsökologie des Trauerschnäppers (Ficedula h. hypoleuca Pallas). Zoologische Jarhbücher 87:185-230.

Dhondt, A. A., F. Fierens, M. Lambrechts, F. ADRiAensen, E. Matthysen, J. De Laet, AND L. BiJNENS. 1987. The establishment of a breeding population of the Pied Flycatcher, Ficedula hypoleuca, in the Peerdsbos, near Antwerp. Le Gerfaut 77:333-339.

EEVA, T., AND E. LeHIKOINEN. 1998. Local survival rates of the Pied Flycatcher (Ficedula hypoleuca) and the Great Tit (Parus major) in an air pollution gradient. Ecoscience 5:46-50.

ENEMAR, A. 1948. Några erfarenheter från fem års holkstudier. Vår Fågelvärld 7:105-117.

GreenwoOD, P. J., AND P. H. HARveY. 1982. The natal and breeding dispersal of birds. Annual Review of Ecology and Systematics 13:1-21.

HAARTMAN, L. vON. 1960. The ortstreue of the Pied Flycatcher. Pages 266-273 in Proceedings XII International Ornithological Congress (G. Bergmann, K. O. Donner, and L. von Haartman, Eds.). Tilgmannin Kirjapaino, Helsinki.

Harvey, P. H., P. J. Greenwood, B. Campbell, AND M. J. Stenning. 1984. Breeding dispersal of the Pied Flycatcher (Ficedula hypoleuca). Journal of Animal Ecology 53:727-736.

Harvey, P. H., P. J. Stenning, and B. Campbell. 1988. Factors influencing reproductive success in the Pied Flycatcher. Pages 189-200 in Reproductive success. Studies of Individual Variation in Contrasting Breeding Systems (T. H. CluttonBrock, Ed.). University of Chicago Press, Chicago.

HemborG, C., AND A. LundBerg. 1998. Costs of overlapping reproduction and moult in passerine birds: An experimental with the Pied Flycatcher. Behavioral Ecology and Sociobiology 43:19-23.

HemborG, C. 1999. Sexual differences in moultbreeding overlap and female reproductive costs in Pied Flycatchers, Ficedula hypoleuca. Journal of Animal Ecology 68:429-436.

HöGSTEDT, G. 1981. Should be a positive or a negative correlation between survival of adults in a bird population and their clutch size? American Naturalist 118:568-571.

JÄRVI, T., E. RøSKAFT, M. BAKKEN, AND B. ZUMSTEG. 1987. Evolution of variation in male secondary sexual characteristics. A test of eight hypotheses applied to Pied Flycatchers. Behavioral Ecology and Sociobiology 20:161-170.

JÄRVINEN, A. 1983. Breeding strategies of hole-nesting passerines in northern Lapland. Annales Zoologici Fennici 20:129-149.

JÄRVINEN, A. 1993. Spatial and temporal variation in reproductive traits of adjacent northern Pied Flycatcher Ficedula hypoleuca populations. Ornis Scandinavica 24:33-40.

KarR, J. R., J. D. Nichols, M. K. KLimkiewicz, AND J. D. BRAWN. 1990. Survival rates of birds of tropical and temperate forests: Will the dogma survive? American Naturalist 136:277-291.

Kendall, W. L., J. D. Nichols, AND J. E. Hines. 1997. Estimating temporary emigration using capture-recapture data with Pollock's robust design. Ecology 78:563-578.

Lebreton, J. D., K. Burnham, J. Clobert, and D. R. ANDERSON. 1992. Modeling survival and testing biological hypotheses using marked animals: A unified approach with case studies. Ecological Monographs 62:67-118.

LundberG, A., AND R. V. Alatalo. 1992. The Pied Flycatcher. Poyser, London.

MARTIN, T. E. 1995. Avian life history evolution in relation to nest sites, nest predation, and food. Ecological Monographs 65:101-127.

Martin, T. E., J. Clobert, AND D. R. ANderson. 1995. Return rates in studies of life history evolution: Are biases large? Journal of Applied Statistics 22:863-875.

NYHOLM, N. E. I. 1986. Birth area fidelity and age at first breeding in a northern population of Pied Flycatcher Ficedula hypoleuca. Ornis Scandinavica 17:249-252.

NyHOLM, N. E. I., AND H. E. MYhrberG. 1983. Breeding area fidelity of the Pied Flycatcher Ficedula hypoleuca at Ammarnäs, Swedish Lapland. Ornis Fennica 60:22-27.

PÄRT, T., AND L. Gustafsson. 1989. Breeding dispersal in the Collared Flycatcher (Ficedula albicollis): Possible causes and reproductive consequences. Journal of Animal Ecology 58:305-320.

PotTI, J., AND S. MonTALvo. 1991a. Male colour variation in Spanish Pied Flycatchers Ficedula hypoleuca. Ibis 133:293-299.

PotTI, J., AND S. MonTALVO. 1991b. Return rate, age at first breeding and natal dispersal of Pied Flycatchers Ficedula hypoleuca in central Spain. Ardea 79:419-428.

Roff, D. A. 1992. The Evolution of Life Histories. Chapman and Hall, New York.

RøskAft, E., T. JÄrVI, N. E. I. NYLhOlM, M. VIROLAINEN, W. WiNKEL, AND H. ZANG. 1986. Geo- 
graphic variation in secondary sexual plumage colour characteristics of the male Pied Flycatcher. Ornis Scandinavica 17:293-298.

SÆTHER, B.-E. 1988. Pattern of covariation between life-history traits of European birds. Nature 331: 616-617.

SANZ, J. J. 1995. Environmental restrictions on reproduction in the Pied Flycatcher Ficedula hypoleuca. Ardea 83:421-430.

SANZ, J. J. 1997a. Clutch size manipulation in the Pied Flycatcher: Effects on nestling growth, parental care and moult. Journal of Avian Biology 28:157-162.

SANZ, J. J. 1997b. Geographic variation in breeding parameters of the Pied Flycatcher Ficedula hypoleuca. Ibis 139:107-114.

SIIKAMÄKI, P., AND M. Hovi. 1997. Low male return rate due to clutch enlargements in the Pied Flycatcher (Ficedula hypoleuca). Ecoscience 4:24-28.

Slagsvold, T., AND J. T. Lifjeld. 1988. Plumage colour and sexual selection in the Pied Flycatcher
Ficedula hypoleuca. Animal Behaviour 36:395407.

STEARNS, S. C. 1992. The Evolution of Life Histories. Oxford University Press, Oxford.

Sternberg, H. 1989. Pied Flycatcher. Pages 56-74 in Lifetime Reproduction in Birds (I. Newton, Ed.). Academic Press, London.

Trettau, W. 1952. Planbeeringung des Trauerfliegenschnäppers (Muscicapa hypoleuca) in Hessen. Vogelwarte 16:89-95.

TretTAu, W., AND F. MerKel. 1943. Ergebnisse einer planberingung des Trauerfliegenschnäppers (Muscicapa hypoleuca Pallas) in Schlesien. Vogelzug 14:77-90.

WinKeL, W. 1982. Zum Ortstreu- Verhalten des Trauerschnäppers (Ficedula hypoleuca) im westlichen Randbereich seines mitteloeuropäischen Verbreitungsgebietes. Journal für Ornithologie 123:155-173.

Received 23 February 2000, accepted 13 December 2000. Associate Editor: M. Murphy

ApPENDix. Annual local return rates (percentage) and median dispersal distance (meters) between successive breedings of female Pied Flycatchers in different parts of Europe. Sample sizes are in parentheses.

\begin{tabular}{lccl}
\hline \hline Latitude & Female return rate & Female dispersal & \\
\hline $69^{\circ} 20^{\prime} \mathrm{N}$ & $5.2(115)$ & & \multicolumn{1}{c}{ Reference } \\
$69^{\circ} 03^{\prime} \mathrm{N}$ & $8.49(271)$ & & Järvinen (1993) \\
$68^{\circ} 21^{\prime} \mathrm{N}$ & $11.96(92)$ & & Järvinen (1983, 1993) \\
$65^{\circ} 58^{\prime} \mathrm{N}$ & $8.2(1260)$ & $200-300$ & Hemborg (1999) \\
$62^{\circ} 37^{\prime} \mathrm{N}$ & $4.3(92)$ & 175 & Nyholm and Myhrberg (1983); Nyholm (1986) \\
$62^{\circ} 10^{\prime} \mathrm{N}$ & $15.22(46)$ & & Siikamäki and Hovi (1997) \\
$61^{\circ} 20^{\prime} \mathrm{N}$ & $16.4(832)$ & & Haartman (1960) \\
$60^{\circ} 00^{\prime} \mathrm{N}$ & $13.9(576)$ & & Eeva and Lehikoinen (1998) \\
$59^{\circ} 50^{\prime} \mathrm{N}$ & $7.0(393)$ & & Haartman (1960) \\
$59^{\circ} 00^{\prime} \mathrm{N}$ & $13.6(154)$ & & Lundberg and Alatalo (1992) \\
$56^{\circ} 00^{\prime} \mathrm{N}$ & $27.0(363)$ & & Enemar (1948) \\
$54^{\circ} 35^{\prime} \mathrm{N}$ & $44.0(176)$ & & Haartman (1960); Curio (1959) \\
$52^{\circ} 31^{\prime} \mathrm{N}$ & $49.23(1298)$ & $100-200$ & Lundberg and Alatalo (1992) \\
$52^{\circ} 27^{\prime} \mathrm{N}$ & 24.0 & $400-500$ & Berndt and Sternberg (1969); Sternberg (1989) \\
$52^{\circ} 00^{\prime} \mathrm{N}$ & $23.0(646)$ & C. 115 & Campel (1982) \\
$52^{\circ} 00^{\prime} \mathrm{N}$ & $27.78(198)$ & & Haartman (1960) \\
$51^{\circ} 45^{\prime} \mathrm{N}$ & $33.74(763)$ & 127 & Harvey et al. (1984, 1988) \\
$51^{\circ} 30^{\prime} \mathrm{N}$ & $27.1(340)$ & c. 150 & Creutz (1955) \\
$51^{\circ} 13^{\prime} \mathrm{N}$ & $28.57(14)$ & & Dhondt et al. (1987) \\
$51^{\circ} 00^{\prime} \mathrm{N}$ & $37.5(40)$ & & Trettau (1952) \\
$50^{\circ} 00^{\prime} \mathrm{N}$ & $21.7(115)$ & & Trettau and Merkel (1943) \\
$41^{\circ} 42^{\prime} \mathrm{N}$ & & & Potti and Montalvo (1991a, 1991b) \\
$40^{\circ} 54^{\prime} \mathrm{N}$ & $44.2(437)$ & 159 & This study \\
$40^{\circ} 48^{\prime} \mathrm{N}$ & $35.85(219)$ & 145 & This study \\
\hline
\end{tabular}

